\title{
HIGH ORDER THINKING SKILLS: HOW IS IT INTEGRATED WITH COGNITIVE ASSESSMENT?
}

\author{
Andarini Permata Cahyaningtyas', Yunita Sari², Agrissto Bintang Aji Pradana ${ }^{3}$ \\ andarinipermata@unissula.ac.id ${ }^{1}$,yunitasari@unissula.ac.id² agrisstobintang@ummgl.ac.id $^{3}$ \\ PGSD FKIP Universitas Islam Sultan Agung1,2, \\ PGSD FKIP Universitas Muhammadiyah Magelang³
}

\begin{abstract}
This research aims to develop a HOTS-based cognitive assessment instrument for third grade students of elementary school. The instrument consists of criteria, questions, answer keys, and scoring guidelines. It is a Research and Development (R\&D) with Four-D model: define, design, develop, and disseminate. In the first stage, the curriculum, students' characteristics, lesson material, and learning objective were analyzed. Next, the instrument components were designed starting from determining the materials, then arranging the norm criteria, the question, and the scoring guidelines. The third stage was only conducted until expert appraisal due to the Covid-19 Crisis. Four experts with major in elementary education studies are assigned as reviewers. This instrument is considered to be very valid based on five indicators such as design (0.8), diction and grammar (0.94), content suitability (0.88), completion (0.89), and practicality (0.81). Hence, it is suggested to be used with minor revisions. The final product will be disseminated to some schools in Genuk District Semarang.
\end{abstract}

Keywords: HOTS, cognitive, assessment, curriculum 2013, students

Received: Juni $22^{\text {nd }}, 2020$

Accepted: July $10^{\text {th }}, 2020$

\section{INTRODUCTION}

Curriculum 2013 has been gradually implemented throughout Indonesia in all primary and secondary levels, including elementary schools. This employs a thematic-based design which helps students to think chronologically and in an integrated way. Besides they teach their students values, attitudes, and characters as ways to build students' positive characters (Muhammad \& Saparahayuningsih, 2016). Consequently, the activities in Curriculum 2013 lead them develop their Higher-Order Thinking Skills (HOTS). This issue has been widely discussed by numbers of people from various education backgrounds.

However, people sometimes fail to know what it is about. They merely view that HOTS is always associated to questions complexity. As matter of fact it is more than just improving students' thinking skills through complex questions (Abosalem, 2016). It provides students to think critically of a particular issue and requires them to act and overcome the problem. It gives challenges to everyone who deals 
with educational practices. Teachers should plan and implement appropriate learning strategies in order process and evaluation can go hand in hand. Such condition requires good correlation between both components. Teachers are expected to develop HOTS-based assessment instrument for daily tests, semester test, and school examination as well (Arifin, 2014; Widana, 2017).

HOTS is derived from Bloom's Taxonomy revised by Krathwohl (2002). It consists of six stages of cognitive thinking: remembering (C1), understanding (C2), applying (C3), analyzing (C4), evaluating (C5), and creating (C6). These levels are then divided into two groups, Lower Order Thinking Skills (LOTS) and Higher Order Thinking Skills (HOTS). LOTS relates to remembering, understanding, and applying while analysing, evaluating, and creating are closely related to HOTS.

Furthermore, Krathwohl (2002) explained that each phase in HOTS includes several skills that are needed students to be accomplished: (1) analyzing contains three skills: distinguishing, organizing, and associating; (2) evaluating comprises skills of checking and criticizing; (3) creating involves formulating, planning, and producing or constructing skills. Those phases are assumed to be challenging for students. They need to remember, comprehend, and implement the concepts for mastering the skills. Through HOTS-based learning students are expected to expand and apply the knowledge they have got.

Doing so will encourage students to promote their creative ideas that are hardly achieved by LOTS. HOTS is an advanced skill that is more than just remembering and memorizing the lesson materials (Widana, 2017, Ahmad, et al., 2019). Meanwhile, the aim of HOTS-based learning will be achieved only if the teachers participate in planning, implementing, and evaluating HOTS-based learning (Sudjiono, 2013). It means teachers play an important role to plan, conduct, and evaluate the process to enhance students' higher-order thinking skills. However, elementary school teachers found it difficult in designing the assessments (Suratmi, Laihat, Asnimar, \& Handini, 2020). They know that HOTS is integrated in Curriculum 2013 but the items did not represent HOTS at all.

Sudijono (2013) stated that measurement is an action to measure a particular thing, and comparing things on a certain basis (quantitatively). The second term is the assessment, which means deciding on something by referring to the measurement of good or bad, healthy or sick, clever or stupid, and so on 
(qualitatively). Therefore, evaluation is a process to decide the progress of the subject by comparing it to the predetermined goals and efforts to obtain feedback for future improvements. Based on the form of students' answers, cognitive assessment can be divided into a written test, oral test, and performance test (Azwar, 2012).

In this study, the cognitive assessment instrument is focussed on a written test derived from three kinds of question in form of multiple choices, short answers, and long answers. The development of this instrument is based on the Core Competencies and Kompetensi Dasar (Basic Competencies) in book Theme 1 for $3^{\text {rd }}$ Graders of elementary school. This becomes the novelty of this study because the theme book is the latest revision. There are no other studies which attempt to develop such assessment. Hence, it is considerable to do so and becomes valuable reference for teachers or researchers who conduct the same field of studies.

\section{METHODS}

The aim of this research is composing a product in the form of assessment instrument. The method of this study is R\&D (Research and Development) with Four-D design that consists of four steps: define, design, develop, and disseminate (Thiagarajan, Semmel, \& Semmel, 1974). In the first phase, the researchers analyzed the curriculum, students' characteristics, lesson materials, and learning objectives. Later, the norm criteria, questions, answer keys, and scoring guidelines were arranged. Next, in the second phase, the instrument was validated by four experts: three lectures and one headmaster who expertize in elementary education. The result of the validation process was calculated using Aiken-V formula:

$$
V=\frac{\Sigma s}{N(c-1)}
$$

Notes:

$\mathrm{V}=$ validity score

$\mathrm{s}=\mathrm{r}-\mathrm{l}_{\mathrm{o}}$

$l_{0}=$ the lowest score

$\mathrm{c}=$ the highest score

$r$ = score given by validator 
The score was interpreted using the following criteria:

Table 1. Criteria of Validity Score

$\begin{array}{cc}\text { Range of Validity Score } & \text { Criteria } \\ 0.81-1 & \text { Very valid } \\ 0.61-0.80 & \text { Valid } \\ 0.41-0.60 & \text { Quite valid } \\ 0.21-0.40 & \text { Less valid } \\ 0-0.20 & \text { Not valid }\end{array}$

Besides, the validators gave some suggestions on the instrument to be revised. There were four validators that has been expert in elementary education field for years. Three of them are lecturers in Elementary School Teacher Education Department and the other one is a headmaster from SDN Genuksari 01 Semarang. This process would take time for about a month.

\section{RESULT AND DISCUSSION}

\section{Result}

This research was attempted to create a HOTS-based cognitive assessment instrument. It was made in form of book. The details of the development steps are follows:

1. Define

The researchers conducted need analysis to develop HOTS-based cognitive assessment instrument through some phases:

a. curriculum analysis

Since 2018, Curriculum 2013 was implemented in the third-grade of elementary school. Actually there were a number of competencies in this curriculum and they are designed to be conveyed through a number of themes. It requires teachers to deliver the materials from more than one subject at the same time. Yet only a few of them were selected to be discussed. It was only focused on Theme 1. Also, every student in each grade has their own personal traits. So the instrument was designed based on its characteristic. 
b. Analysis of students' characteristics

It will be used by third-grade students so the questions should be arranged by considering their characteristics as mentioned in the previous explanation. They tend to be interested in colors and pictures. These are powerful tools to convey the materials. They will pay more attention to pages with full of colours and images. That is why this instrument were designed to cope these components.

c. lesson material analysis

This phase was attempted to determine the lesson material so that the instrument was developed according to what students learned. This analysis involved analysis of competencies and other sources that will be used as the basis for instrument development.

d. deciding the learning objective

Learning objectives were decided based on the competencies in each sub theme. This prevented repetition and so that the product was always led to its main purposes.

2. Design

The next step is designing a product that consists of four phases:

a. determining the materials

The chosen material was Theme 1 that is about The Growth and Development of Living Things, and it covers four sub themes: The Characteristics of Living Things, The Growth and Development of Human Beings, The Growth and Development of Animals, and The Growth and Development of Plants. Each sub theme includes learning competencies that would be used as the basic materials in developing the instrument.

b. Arranging the norm criteria

In this phase, norm criteria were arranged based on the competencies, indicators, and learning objectives. The number of the questions were initially decided based on the extent of the materials, and were in form of short and long answer questions.

c. Arranging the questions 
Questions were created when the norm criteria were ready, along with the answer keys. The questions were adjusted to the cognitive level of each sub theme.

d. Arranging the scoring guidelines

Scoring is also a crucial aspect in evaluation. It guides teachers to define the grade to which the students belong. The questions and answer keys that had been completed were then followed by arranging the scoring guide with a scale of $0-3$ and the criteria were considered to be different depending on the questions.

\section{Develop}

The developing phase aimed to produce the final product and to know if it was valid to be disseminated. Three lecturers: Mrs. Nuhyal Ulia (Validator 1), Mrs. Deane Umboh (Validator 2), and Mr. Ari Suryawan (Validator 3); and Mr. Budi Candra Wicaksono (Validator 4), the headmaster of SDN Genuksari 01 all gave opinion as expert judgement.

There were 20 statements to be answered and those were about the book design, diction, grammar, and font that were used in norm criteria, questions, answer keys, scoring guidelines. All of them are developed based on the characteristics of third-grade students in elementary school.

The quantitative data ware statistically calculated using a formula as mentioned before. The instrument could be used when the validity result was between $0.61-1.00$. Here is the recapitulation:

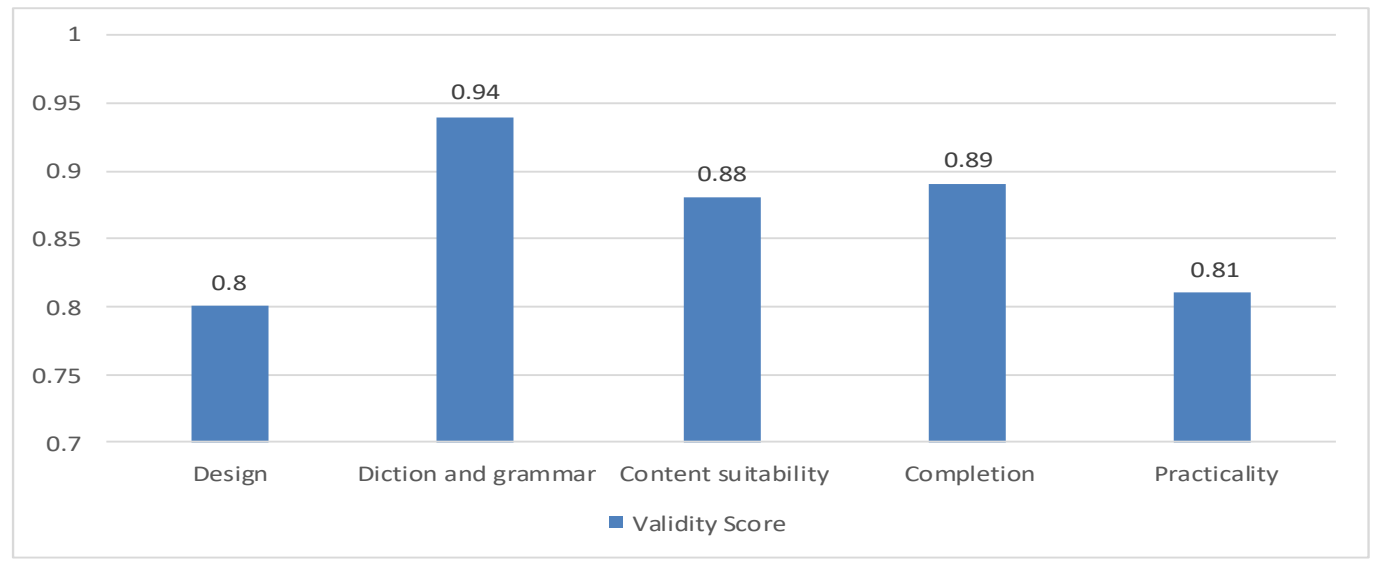

Picture 1 Validity Score 
The result showed that the validity score of each indicator is in a very valid category. This indicated that the instrument can precisely measure what should be measured. However, there are some suggestions proposed by the validators. Here are the details of the suggestions and the revision:

a. Design

1) The images were put in the left part of the page, right under the beginning of the question sentence. Validator 3 suggested to set the picture in the middle if there is only a picture in each page. It has been revised as suggested.

2) Validator 3 also suggested to change the images to real pictures or put the source from which they were taken. Because the most of the images in the book were taken from the theme book and internet, it was then given the original sources.

3) Validator 4 suggested to change the font into Tahoma or Trobuchet, with font size 11 or 12. Originally, the font style used in this book was Futura Bk BT with size 12. However, it was changed into Tahoma size 12.

b. Diction and grammar

1) Validator 4 suggested to put four dots consistently in every short answer question. Primarily, the short answer questions had inconsistent number of the dots, then it was revised as what validator had asked.

2) There were five dots in the fill in the blank questions. Validator 4 suggested to consistently put three dots in fill in the blank questions.

c. Content

1) Validator 4 suggested to vary the question form that includes 15 questions of multiple choices, 5 questions of short answer, and 3 questions of long answer. Originally, the question form was not distinguished whether it was short or long answer, and there was no multiple question. The number of questions per sub-theme also was not the same.

2) Validator 1 suggested to add more clear instructions. The instruction was only one for all kinds of questions. They had better provide clearer instruction about how they answer the questions. 
3) There was only a short description of the authors. Validator 1 also suggested to add a brief biography of each author. But then they provided longer description on authors' biography.

\section{Discussion}

To measure how far the students have mastered HOTS, teachers need to develop a suitable assessment instrument which is able to evaluate students' learning outcomes. The learning process that has been directed to enhance HOTS should be assessed using a HOTS-based instrument. Teachers often find it difficult when they are developing the instrument. Later they have no idea in applying such assessment in their classroom (Okayana, Suntoro, Sabdaningyas, \& Darsono, 2019).

This research aimed to develop a HOTS-based cognitive assessment instrument and to obtain the validity score of the instrument. Here is the discussion about the process to achieve the goals:

The development included four steps to produce HOTS-based cognitive assessment instruments. The steps were define, design, develop, and disseminate. The instrument development was started from a need analysis of the assessment instrument in third grade of elementary school. The analysis showed that many schools had not implemented HOTS-based assessment for the teachers were not ready to create a proper HOTS-based assessment instrument.

After deciding the product, curriculum analysis began to conduct. This phase was conducted to gain information about what curriculum that had been implemented in the third grade of elementary school, and it was found that they had been implementing Curriculum 2013 since 2018.

Second, students' characteristic analysis was carried out to know the extent of his cognitive development and what kind of characteristics they have. This intended to be able to produce a good instrument. Students will be attracted to everything which fits to their personal traits. Next, lesson material analysis was conducted to know deeper about the subtheme and its competencies. Then, the last one was deciding the learning objectives based on the competencies. Every component in the instrument should be referred to the competencies on which this study was focus.

Moreover, the second step was to design the instrument. This step contained some phases such as determining the materials; arranging the norm criteria, 
questions, answer keys, and scoring guidelines; and the last process was creating the cover, table of contents, preface, and the synopsis. After the learning objectives were decided, the scope of the materials should be limited so it would not widen. Then, the norm criteria were arranged to determine how many questions of each objective. This needed to be prepared carefully supposed to make a balanced number of questions in every subtheme. Next, the questions and answer keys were developed based on the norm criteria. The questions and answers were based on the materials that had been decided before so there would not be any questions that had not been thought by teachers. Furthermore, the scoring guidelines were created by considering the extent of the questions and answers. The scale of the score was 0-3 of each question. Lastly, cover, table of contents, preface, and synopsis were created and arranged to complete the contents of the book.

Next, the third step was developing the instrument. It was conducted to know about the validity. The content validity test was conducted by giving the book to the experts. Overall, the validity score of each indicator (design, diction and grammar, content suitability, completion, and practicality) showed a range between 0.8-0.94. The highest validity score was gained by diction and grammar, while design got the lowest score. There were also some suggestions from the validators. They were included into three indicators, except completion and practicality: (a) design: about images' positions that should be in the middle, the sources were needed to be deleted if they were not real, and also the font style should be changed into Tahoma that was considered as a more clear font style for third-grade students; (b) diction and grammar: consistency on the number of dots in short answer and fill in the blank questions; and (c) content suitability: needs to provide clearer instructions and a brief biography of the authors, and varying the question form.

This HOTS-based assessment instrument of Theme 1 for third grade of elementary school has its own components which distinguish to other studies. This instrument provided a complete assessment component such as norm criteria, questions, answer keys, and scoring guidelines. Furthermore, the questions were arranged in various question forms, so this will be easier for elementary school students to learn how HOTS-based questions are presented and how to solve that as what Dewi (2018) stated that the assessment used must provide opportunities for students to be actively involved and engaged in the learning process. Moreover, 
teachers can also use this book as a guide for them to develop other them assessment instrument in the future because assessment helps educators to make decisions about students' needs, and guidance on planning the next learning process (Kurniawati \& Sukardiyono, 2018). If the assessment is arranged in a various form, teachers can gain more information about their students' achievement and difficulties. However, this instrument only put out three last stages of the Bloom's Revised Taxonomy which are analyzing, evaluating, and creating. It does not consist of any LOTS-based questions.

Besides, as we know that third grade of elementary school has become the latest grade that implemented Curriculum 2013, this instrument was developed based on the latest revision of Theme 1 for third grade of elementary school. So, there were rarely people who have developed HOTS-based cognitive instrument based on this theme and grade. Moreover, this research is an initial study to find how effective a complete HOTS-based cognitive instrument in assessing HOTS-based learning in elementary school. This could also inspire other researchers or elementary school teachers to conduct a similar development based on other themes. If this kind of instrument are able to give positive and significant result to improve third grade students' higher order thinking skills, the quality of education in elementary school in Indonesia will be enhanced too.

\section{CONCLUSION}

The HOTS-based assessment instrument has been developed through three steps. First was defining the curriculum, students' characteristics, the lesson materials, and the learning objectives. After that, norm criteria, questions, answer keys, and scoring guidelines were arranged. Last, the product was evaluated on its content validity based on five indicators: design, diction and grammar, content suitability, completion, and practicality. It was also validated by four experts. The validity scores were $0.8,0.94,0.88,0.89$, and 0.81 and assumed to be very valid. Besides, the validators also gave suggestions related to the deficiencies. However, the phase was only conducted to the expert appraisal due to the Covid - 19 pandemics. The final product will be disseminated to some schools in Genuk District Semarang. This instrument is a model of assessment which promotes students' critical thinking. It matches the requirements of existing curriculum that expects 
them to view beyond what they merely see. Also, it provides questions focused on cognitive aspect. Hence, the product of prior study will give significances to elementary school teachers in integrating High Order Thinking Skills with cognitive assessment.

\section{REFERENCES}

Abosalem, Y. (2016). Assessment techniques and students' higher order thinking skills. International Journal of Secondary Education, Vol. 4 (1), 1-11. DOI: 10.11648/j/ijsedu.20160401.11.

Ahmad, S., et al. (2019). Instrument higher order thinking skill design in course highclass mathematics in elementary school teacher of education department. Journal of Physics: Conference Series, 1321, 1-8. DOI: 10.1088/17426596/1321/2/022129.

Arifin, Z. (2014). Evaluasi Pembelajaran: Prinsip, Teknik, Prosedur. Bandung: PT. Remaja Rosdakarya.

Azwar. (2012). Tes Prestasi. Yogyakarta: Pustaka Pelajar

Dewi, K.T. (2018). Developing assessment instrument based curriculum 2013 for teaching micro teaching in English education department of Undiksha. International Journal of Social Science and Humanities, Vol. 2 (3), 96-106. DOI: 10.29332/ijssh.v2n3.205.

Kurniawati, A., \& Sukardiyono. (2018). The development of authentic assessment instrument to measure science process skill and achievement based on students' performance. Jurnal Penelitian dan Pengembangan Pendidikan Fisika, Vol. 4 (2), 65-74. DOI: 10.21009/1.04203.

Krathwohl, D.R. 2002. A Revision of Bloom's Taxonomy: An Overview. Theory into Practice, vol.41 (4), 212-218.

Muhamad, B., \& Saparahayuningsih. (2016). An attitude and character instructional development based on curriculum 2013 in elementary school. Creative Education, Vol. 7 (2), 269-277. DOI: 10.4236/ce.2016.72025.

Okayana, K., Suntoro, I., Sabdaningtyas, L., \& Darsono. (2019). The development of higher order thinking skill-based assessment instrument for elementary school integrated thematic learning. Journal of Education and Practice, Vol. 10 (15). DOI: $10.7176 / J E P$.

Sudjiono, A. (2013). Pengantar Evaluasi Pendidikan. Jakarta: PT. Raja Grafindo Persada. 
Suratmi, Laihat, Asnimar, \& Handini, E.O. (2020). Teachers understanding of HOTS based assessment in elementary school. Proceeding of The $2^{\text {nd }}$ International Conference on Elementary School, Vol.2 (1), 1157-1164.

Thiagarajan, S., Semmel, D.S., \& Semmel, M.I. (1974). Instructional Developmet for Training Teacher of Exceptioal Children: A Source Book. Indiana: Indiana University.

Widana, I.W. (2017). Higher order thinking skills assessment (HOTS). Journal of Indonesian Student Assessment and Evaluation, Vol.3 (1), 32-44. 